\title{
原著
}

Comparative genomic hybridization $(\mathrm{CGH})$ 法を用いた 大腸癌臟器転移に関連するゲノムコピー異常の網羅的解析

\begin{tabular}{|c|c|c|c|c|c|c|c|c|c|c|}
\hline \multicolumn{11}{|c|}{ 順天堂大学下部消化管外科 } \\
\hline 山 & 博 & 彦 & 鵜 & 清争 & & 条 & 石 & 戸 & 保 & 典 \\
\hline 沼 & 行 & 宏 & 笠 & 巻 & 伸 & 二 & 坂 & 本 & 一 & t \\
\hline 藤 & 孝 & 之 & 丹 & 羽 & & -郎 & 鎌 & 野 & 俊 & 䊽 \\
\hline
\end{tabular}

\section{Analysis of DNA Copy-number Aberrations related with Organ Metastases of Colorectal Cancer by Comparative Genomic Hybridization}

\author{
Hirohiko KAMIYAMA, Jo UNOTORO, Yasunori ISHIDO, \\ Yukihiro YAGINUMA, Shinji KASAMAKI, Kazuhiro SAKAMOTO, \\ Takayuki SHINDO, Shinichiro NIWA and Toshiki KAMANO \\ Department of Coloproctological Surgery, Juntendo University School of Medicine
}

（目的）大腸癌の臟器転移は大腸癌の予後規定因子として重要である。大腸癌臟器転移にかかわる遺伝子を抽 出するため, CGH法を用いて大腸癌原発巣に生じたゲノムコピ一異常を網羅的に解析した。(対象および方法)当 科で2003年 4 月から 2004 年12月に手術を施行した大腸癌症例 43 例（非臓器転移30例, 同時性肝転移 8 例, 同時性 肝および肺転移 5 例)。手術で得られた大腸癌原発巣の新鮮凍結切片から, microdissectionにより腫瘍細胞の DNAを抽出し, CGH法で解析した。解析結果を臓器転移群と非藏器転移群とで比較検討した。

（結果）大腸癌の同時性臟器転移群における3q13.3，5p12, 14q24のゲノムコピーの増加が非臓器転移群に比 へ，有意に多く認められた。

(結語) 3q13.3, 5p12,14q24のゲノムコピーの増加が大腸癌の臟器転移に関与している可能性が示唆された。

索引用語 : 大腸癌 (colorectal cancer), 臓器転移 (organ metastases), 遺伝子 (gene), ゲノム (genome), $\mathrm{CGH}$ (comparative genomic hybridization)

\section{緒言}

近年, 我が国では大腸癌は急激な増加をたどり， 大腸癌研究会1)の発表したガイドラインによると 全病期での累積 5 年生存率は $69.9 \%$ であるが, 臓 器転移を認めるStageIVでは $13.2 \%$ とだ惨澹た るものである。

一方, 癌はさまざまな遺伝子変化の蓄積によっ て発生することが明らかにされ，その生物学的悪 性度を遺伝子変化によってとらえようとする試み


唱したadenoma-carcinoma sequenceにみられる ようにその遺伝子変化の解析が明らかにされつつ ある癌の一つである。その遺伝子変化の解析はこ れまでにsouthern blotting法やrestriction fragment length polymorphism (RFLP) 法などが試 みられているが, 検索できる遺伝子や染色体領域 が限られているという難点がある。さらに, 固形 腫瘍では複雑な染色体異常を呈するため遺伝子変 化の解析が困難とされてきた。しかし，1992年に 
Kallioniemi ら゙)によってfluorescence in situ hybridization (FISH) 法をもとに開発された比較 遺伝子競合comparative genomic hybridization (CGH) 法は，これらの難点を解消した極めて優 れた方法である。癌細胞の遺伝子変化には染色体 の増加・減少に由来する比較的大きなものから, 遺伝子を構成する一つの核酸の置換による小さな ものまでさまざまなものがあるが, CGH法は遺伝 子変化のうちでも染色体レベルでのゲノムコピー の増加・減少を検出し, その染色体領域を同定す ることができる。すなわち，固形腫瘍において腫 瘍DNA中の染色体レベルでのゲノムコピーの増 加・減少を一度に網羅的に検出し，しかも同時に 全ての染色体上にそれらの領域を同定することが できる。

そこで今回, このCGH法を用いて大腸癌の臟器 転移に関わる遺伝子変化について解析した。

\section{対象および方法}

1) 患者と組織検体：当科で2003年 4 月から 2004年12月に手術を施行した大腸癌症例 43 例を対 象とした。内訳は, 同時性肝転移 8 例, 同時性肝・ 肺重複転移 5 例, 非蔵器転移30例である。全ての 症例に当院の倫理委員会の定める遺伝子解析に関 する説明を行い，同意を得ている。

手術で得られた大腸癌原発巣の腫瘍組織の凍結 標本をクライオスタットで16 $\mu \mathrm{m}$ の厚さに薄切 し，組織切片スライドを作成した。ここから $\mathrm{mi}$ crodissectionにより癌細胞のみを選択的に採取 し, 癌組織のゲノムDNAを抽出した。

2 ) CGH解析：腫瘍DNAに緑色の, 正常DNA に赤色の蛍光標識を行った後，単鎖化処理を行っ た。Cot-1 DNAの存在下に正常男性ヒトリンパ球 分裂中期染色体に上記の腫瘍DNAと正常DNAを ハイブリダイズさせた。これにDAPI（4，6diamino-2-phenylindole) で対比染色を行った 後, CCDカメラ付の蛍光顕微鏡を使用して染色体 蛍光画像を取り込んだ。各染色体の長軸上に緑色 および赤色の蛍光強度曲線を描き，緑色の赤色に 対する蛍光強度比を計算した。強度比 1.0 を基準線 とし，1.2以上をゲノムコピーの増加，0.8以下を ゲノムコピーの減少と判定した。
3 ) 統計処理 : CGH解析によりゲノムコピー の増加・減少が判明した染色体領域ごとに藏器転 移群と非臓器転移群とで統計学的な有意差を検定 した。有意差の検定にはFisherの直接法を用い, P 值0.05末満を有意差ありとした。

\section{成 績}

臓器転移の有無別の背景はTable 1 に示す如 く, 年齢, 性別, 腫瘍占居部位, 組緎型分類, 深 達度, 所属リンパ節転移度に関して有意差を認め なかった。われわれのCGH解析でゲノムコピーの 増加・減少を判定した393箇所の染色体領域のう ち, 3q13.3, 5p12, 14q24のゲノムコピーの増加が 非藏器転移群に比べ, 藏器転移群に有意に多く認 められた (Table 2)。上記の染色体領域において 各症例で認められたゲノムコピーの増加・減少を Fig. 1 に示す。ゲノムコピー異常の認められた染 色体領域の平均数は, 藏器転移群で 1 症例あたり 増加16.1箇所, 減少 6.46 箇所, 非臟器転移群で増 加16.3箇所, 減少6.87箇所であった (Fig. 2)。

\section{考察}

CGH法の原理は, 蛍光色素で標識した腫瘍細胞 のDNAと正常細胞のDNAを正常細胞分裂中期染 色体に競合的にハイブリダイズさせると，腫瘍 DNAの特定の染色体領域にゲノムコピーの増加 があればそれが腫瘍DNAの蛍光の増加として検 出され，ゲノムコピーの減少があれば逆に正常 DNAの蛍光の増加として検出されるというもの である。これにより腫瘍細胞の遺伝子変化の特徵 をとらえることができる。CGH解析結果の利用に は主に二つの方法がある。一つは臨床病理学的事 項との関連を統計学的に検討して診断や予後と相 関する染色体異常領域を同定し臨床応用すること であり，もう一つはその染色体異常領域のさらに 詳細な分析から癌関連遺伝子を同定することであ る。

われわれはDNAの抽出に際し, microdissectionを行うことで腫瘍細胞以外のDNAの影響を できる限り少なくした。また, 腫瘍組織検体から DNAを抽出しているため, 培養細胞を用いた実験 系に比べて特定の細胞集団が選択されるような偏 
Comparative genomic hybridization（CGH）法を用いた大腸癌臟器転移に関連するゲノムコピー異常の網羅的解析

Table 1 Characteristics of the Patients and Tumors.

\begin{tabular}{|c|c|c|c|}
\hline & & CRC With Organ Metastases & CRC Without Organ Metastases \\
\hline Age(SD) & & $\begin{array}{c}13 \\
65.6(9.99)\end{array}$ & $\begin{array}{c}30 \\
65.9(11.2)\end{array}$ \\
\hline \multirow[t]{2}{*}{ SEX } & Male & 5 & 15 \\
\hline & Female & 8 & 15 \\
\hline \multirow[t]{8}{*}{ Tumor site } & C & 2 & 1 \\
\hline & A & 1 & 8 \\
\hline & $\mathbf{T}$ & 1 & 2 \\
\hline & D & 2 & 1 \\
\hline & $\mathbf{s}$ & 3 & 7 \\
\hline & Rs & 2 & 4 \\
\hline & $\mathbf{R a}$ & 1 & 2 \\
\hline & $\mathbf{R} \mathbf{b}$ & 1 & 5 \\
\hline \multirow[t]{5}{*}{ Histology } & well & 4 & 14 \\
\hline & moderate & 8 & 12 \\
\hline & poorly & 0 & 2 \\
\hline & mucinous & 1 & 1 \\
\hline & others & 0 & 1 \\
\hline \multirow[t]{6}{*}{ Depth } & $\mathbf{m}$ & $\mathbf{0}$ & 0 \\
\hline & sm & $\mathbf{0}$ & $\mathbf{0}$ \\
\hline & mp & 1 & 3 \\
\hline & ss(a1) & 5 & 18 \\
\hline & se(a2) & 5 & 7 \\
\hline & si(ai) & 2 & 2 \\
\hline \multirow[t]{4}{*}{ pN } & 0 & 2 & 14 \\
\hline & 1 & 7 & 10 \\
\hline & 2 & 1 & 3 \\
\hline & 3 & 3 & 3 \\
\hline
\end{tabular}

Table 2 Imbalances of $3 q 13.3,5 p 12$ and $14 q 24$ in the two groups of Colorectal cancer.

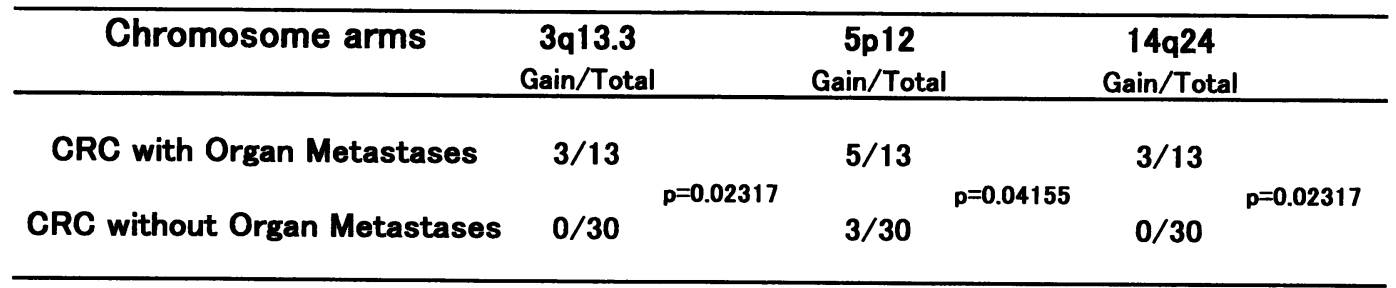

クは少ないものと考えられる。全ての検体は腫瘍 の表層部を約 $5 \mathrm{~mm}$ 角のブロック状に採取して凍 結標本を作成しているので, 腫瘍細胞間の差はほ ぼないものと考えられる。しかし，今回の解析結 果が経時的な遺伝子変化のうちの一時点での染色 体異常の特徵をとらえたに過ぎない可能性は否定 できない。

DeAngelisら ${ }^{4}$ は, Dukes C/D症例はDukes B症 例に比べてゲノムコピーの異常が多く認められた としている。すなわち癌の進行にしたがってゲノ ムコピーの異常が増えていく可能性を示唆してい る。癌の進展が遺伝子変化の蓄積によって起こる とすれば, 臓器転移を有するような進行した癌細 胞においてはゲノムコピーの異常がより増加する という結果は理解しやすい。しかし，われわれの
$\mathrm{CGH}$ 解析結果においてゲノムコピー異常の認め られた染色体領域の平均数は, 臟器転移群と非藏 器転移群の間に有意差は認められなかった（Fig. 2 )。この結果は, 癌細胞と周囲の間質や細胞との 相互作用などの遺伝子変化以外の因子も癌の進展 に関与している可能性を示唆していると考えるこ ともできるが，われわれの解析では非臓器転移群 の中にリンパ節転移を有するものが含まれている ため, 両群間の検討が必ずしも癌の進展の程度を 正確に反映していない可能性も否定できない。

われわれの解析では藏器転移に肝と肺を含めて いるため, 純粋な比較はできないが, Nakaoら 大腸癌原発巣の検討から $6 \mathrm{q}, 7 \mathrm{q}, 8 \mathrm{q}, 13 \mathrm{q}, 20 \mathrm{q}$ の 増加が肝転移を有する群に有意に多く認められた ことを報告している。また, Diepら ${ }^{6)}$ は過去に報告 


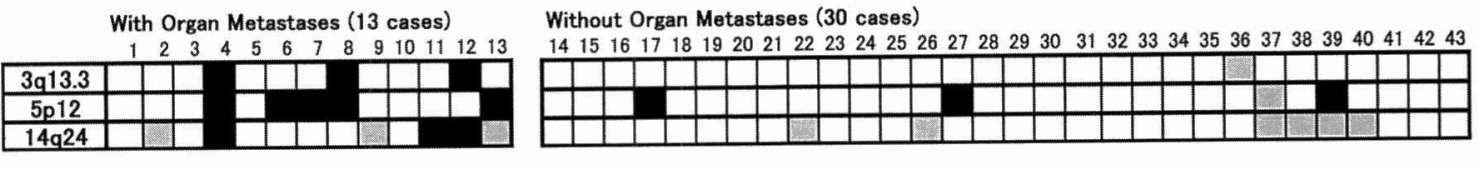

口: Gain, $\mathbf{a}$ : Loss, $\square:$ Neither Gain nor Loss

Fig. 1 Genomic aberrations in 3q13.3, 5p12 and 14q24.

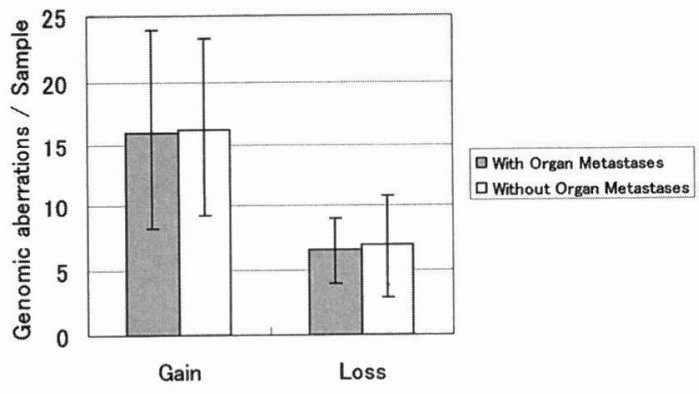

Fig. 2 The mean number of genomic aberrations.

された大腸癌のCGH解析結果の集計から, 7pの増 加および15qの減少が蔵器転移に関与している可 能性があるとしている。われわれの解析結果では これらの染色体領域に関して臓器転移群と非藏器 転移群との間に有意な差は認められなかった。

今回，われわれの解析では3q13.3，5p12，14q24 のゲノムコピーの増加が藏器転移を有する大腸癌 原発巣に有意に多く認められた。3q13.3に存在す るIGSF11遺伝子は胃癌で高度に発現しており, 接 着分子の一つとされている7)。接着分子の動態は 癌の転移・浸潤機構に重要な役割を果たしている ことが予想される。 $5 \mathrm{p} 12$ は卵巣癌の予後不良症例 において増加しているとの報告があり8), 癌の進 展に関与している可能性を示唆している。5p13p12に存在するFGF10は, 胚発生や細胞成長・形態 発生・組織修復をはじめ腫瘍の成長や浸潤に関与 するといわれるFGFファミリーのうちの一つで あり，マウス乳腺における癌遺伝子であるとの報 告がある99。14q24.3に存在するFOSは細胞骨格の 形成と維持に関与しているとされており, この転 写因子fos 1 が基底膜を超える癌の浸潤に関与して いるとされる10)。

これらの報告からも，われわれが初めて報告す る3q13.3, 5p12, 14q24には大腸癌の臓器転移に関 与する遺伝子が存在している可能性や大腸癌の子 後不良因子に関与している可能性が示唆される。
ただし, 肝・肺の各々の特徵についてはさらなる 解析結果の蓄積と検討が必要である。

今後, 分子生物学的なアプローチにより得られ た知見と遺伝子解析で得られた情報が関連づけら れ，大腸癌の発生および転移のメカニズムが解明 されると考える。また，早期診断や転移の予測， 予防医学，遺伝子診断や治療の分野で大腸癌の子 後の向上に寄与することが期待される。

\section{結 語}

3q13.3, 5p12, 14q24のゲノムコピーの増加が大 腸癌の臓器転移に関与している可能性が示唆され た。

\section{参考文献}

1）大腸癌研究会編：大腸癌治療ガイドライン. 金原 出版, 東京, 2005, 19-23

2) Vogelstein B, Fearon ER, Hamilton SR, et al : Genetic alterations during colorectal-tumor development. N Engl J Med 319 : 525-532, 1988

3) Kallioniemi A, Kallioniemi OP, Sudar D, et al : Comparative genomic hybridization for molecular cytogenetic analysis of solid tumors. Science 258: 818-821, 1992

4) DeAngelis PM, Clausen OP, Schjolberg A, et al: Chromosomal gains and losses in primary colorectal carcinomas detected by $\mathrm{CGH}$ and their associations with tumor DNA ploidy, genotypes and phenotypes. Br J Cancer $80: 526$ $-535,1999$

5) Nakao K, Shibusawa M, Ishihara A, et al: Genetic changes in colorectal carcinoma tumors with liver metastases analyzed by comparative genomic hybridization and DNA ploidy. Cancer 91 : 721-726, 2001

6) Diep CB, Teixeira MR, Thortensen L, et al: Genome characteristics of primary carcinomas, 
Comparative genomic hybridization（CGH）法を用いた大腸癌蔵器転移に関連するゲノムコピー異常の網羅的解析

local recurrences, carcinomatoses, and liver metastases from colorectal cancer patients. Mol Cancer $3: 6,2004$

7) Katoh $M$, Katoh $M:$ IGSF11 gene, frequently up regulated in intestinal-type gastric cancer, encodes adhesion molecule homologous to CXADR, FLJ22415 and ESAM. Int J Oncol 23 : 525-531, 2003

8) Partheen K, Levan K, Osterberg L, et al : Analysis of cytogenetic alterations in stage III serous ovarian adenocarcinoma reveals a heterogeneous group regarding survival, surgical outcome, and substage. Genes Chromosomes Cancer $40: 342-348,2004$

9) Theodorou V, Boer M, Weigelt B, et al: Fgf10 is an oncogene activated by MMTV insertional mutagenesis in mouse mammary tumors and overexpressed in a subset of human breast carcinomas. Oncogene 23 :6047-6055, 2004

10) Sherwood DR, Butler JA, Kramer JM, et al: FOS-1 promotes basement-membrane removal during anchor-cell invasion in C. elegans. Cell $121: 951-962,2005$ 